\title{
Assessment of Soil Infiltration Capability in Balikpapan City
}

\author{
Ratna Juwita $^{1}$ and Irwan Bagyo Santoso ${ }^{1}$
}

\begin{abstract}
This study aims to determine the ability of soil infiltration in the city of Balikpapan. The analysis begins by testing the infiltration rate in the field using Double-ring Infiltrometer. Measurements were made in 15 research locations spread across Balikpapan City. Location determination is seen from changes in land and soil type functions in Balikpapan City based on regional administrative maps, land type maps, land use maps and Balikpapan City RTRW. Furthermore, the results of field measurements are processed using the Horton model. The Horton model is one of the well-known infiltration models in hydrology. From the results of research at 15 locations, it was concluded that Balikpapan City had an infiltration rate between the range of 12 mm / hour to $240 \mathrm{~mm} /$ hour. Based on U.S. Soil Conservation, the infiltration rate classification in Balikpapan City is divided into four infiltration rate classes, namely fast, rather fast, medium and rather slow. Areas that have the potential to be rainwater catchment areas are seen from areas that have as many as 10 locations from 15 locations, namely Prapatan, Telaga Sari. Sources Rejo, Manggar Baru, Damai Baru, Kariangau, Gunung Sari Ulu, Margo Mulyo, Graha Indah and Mount Bahagia. So the area that has the potential as a catchment area is around $60 \%$ of all research locations. From the analysis results obtained by the type of rainwater management facilities in the form of PAHs and / or retention facilities for housing, education, trade and services with rapid, rather rapid infiltration, while PAHs and / or retention facilities and / or detention facilities for infiltration rates. a little slow.
\end{abstract}

Keywords-Infiltration Rate, Horton Model, BMP, Retention, Detention.

\section{INTRODUCTION}

The rapid development and settlements have caused a reduction in rainwater catchment areas. The reduction in rainwater catchment areas in urban areas will result in increased water runoff and cause flooding and inundation [1]. Infiltration is the process of water flowing into the soil and causing an increase in total water content, contributing to variations in water partitions and hydrological responses [2]-[4]. Infiltration is important in hydrology because this process regulates available water reserves for groundwater filling and controls water runoff and soil erosion [5]. Infiltration rate measurements generally use the Horton Model.

\footnotetext{
${ }^{1}$ Ratna Juwita and Irwan Bagyo Santoso are with Department of Environmental Engineering, Faculty of Civil, Environmental and Geo Engineering, Institut Teknologi Sepuluh Nopember, Surabaya, 60111, Indonesia. E-mail: ratnajuwita.by@gmail.com; irwan080565@gmail.com.
}

The Horton model is one of the well-known infiltration models in hydrology compared to other models. Infiltration can be expressed in two dimensions, namely infiltration capacity and infiltration rate expressed in $\mathrm{mm} /$ hour. Infiltration capacity is the maximum infiltration rate for a particular type of soil, while the infiltration rate is the rate of infiltration whose value depends on soil conditions and rainfall intensity. The capacity of soil infiltration is the maximum rate of soil to absorb water under certain conditions [6]. Infiltration capacity occurs when the rain intensity exceeds the ability of the soil to absorb soil moisture. Conversely, if the rainfall intensity is smaller than the infiltration capacity, then the infiltration rate is the same as the rainfall rate. Infiltration rate data can be used to predict when a run-off will occur if a type of soil has received a certain amount of water, either through rainfall or irrigation from a water reservoir on the ground.

The catchment area is essentially an area that is provided for the entry of air from the soil surface into the air saturation zone so as to make a flow in the soil. The function of the air catchment area itself belongs to the authorities to discharge the rainwater that falls in the area. Water catchment areas play an important role as controlling floods and droughts in the dry season. This happens because rainwater that falls in the rainy season is not accommodated on the ground as a result of ground air no longer exists.

In this study, the rate of infiltration rate and capacity can be known as infiltration of Best Management Practices (BMPs) that can be used at the location of withdrawal of money, rainwater must be managed, not activated, transferred to the air body. Rainwater must be absorbed as much as possible into the soil to increase water reserves in the dry season. In addition, more soil water content can prevent intrusion of seawater which can contaminate people's wells.

\section{METHOD}

\section{A. Data Collection and Field Surveys}

The preliminary data needed in this study are the map of the administrative area, the soil type map, the land use map and the map of the plan for the Balikpapan City Spatial Plan. The data is used as a basis for determining the location in Balikpapan to be used as the location for field data collection (primary data). Location determination seen from changes in land and soil type functions in Balikpapan 
City based on regional administrative maps, land types, land use maps and Balikpapan City RTRW. The research locations were 15 locations spread across 14 villages, namely

Gunung Sari Ulu Village (GSU) and Sumber Rejo Village (SR) in Central Balikpapan Subdistrict, in Teritip Sub-District there are 2 research locations (T1 and T2) and Manggar Baru Village (MB) in Balikpapan East SubDistrict, Sepinggan Baru Village (SB), Damai Baru Village (DB) and Gunung Bahagia Village (GB) in West Balikpapan Sub-District, Prapatan Village (Prap) and Telaga Sari Village (TS) in City Balikpapan Sub-District, Kelurahan Kariangau Village (Kari) and Kelurahan Margo Mulyo Village (MM) in West Balikpapan District, Karang Joang Village (KJ), Graha Indah Village (GI) and Batu Ampar Village in North Balikpapan Sub-District. The research locations spread across Balikpapan City can be seen in Figure 1.

\section{B. Infiltration Rate Measurement}

Conduct infiltration rate tests at 15 predetermined locations in the Balikpapan City area. Method The measurement of infiltration rate is carried out using a Double-ring infiltrometers. Where the tool is made of steel, the diameter of the middle ring is $28 \mathrm{~cm}$ and the height is $30 \mathrm{~cm}$, and the outer ring is $53 \mathrm{~cm}$ in diameter with a height of $30 \mathrm{~cm}$. For certain purposes, ring sizes are often used larger or smaller. The use of a ring that is too small also causes a higher level of error [7]. Record the decrease in water at infiltration test points.

\section{Processing of Measurement Data Results}

From the measurements in the field data obtained in the form of the magnitude of the decrease in water from 15 research locations. The data is then processed and the infiltration rate data is obtained at each time ( $\mathrm{ft}$ ) and constant infiltration (fc). Analysis of infiltration rate and infiltration capacity will be carried out using the Horton model. The equation for calculating the infiltration rate and infiltration capacity is as follows:

$$
f=f c+(f o-f c) e^{-K t}
$$

$\mathrm{f}(\mathrm{t}) \quad=$ infiltration rate at $\mathrm{t}$ measured from the start of the experiment $(\mathrm{cm} /$ minute)

$\mathrm{fc} \quad=$ constant infiltration rate $(\mathrm{cm} /$ minute $)$

fo = infiltration rate at the beginning of measurement (cm / minute)

$=$ constant decrease in infiltration rate

$=$ exponential number $(2,718)$

$=$ time (minutes)

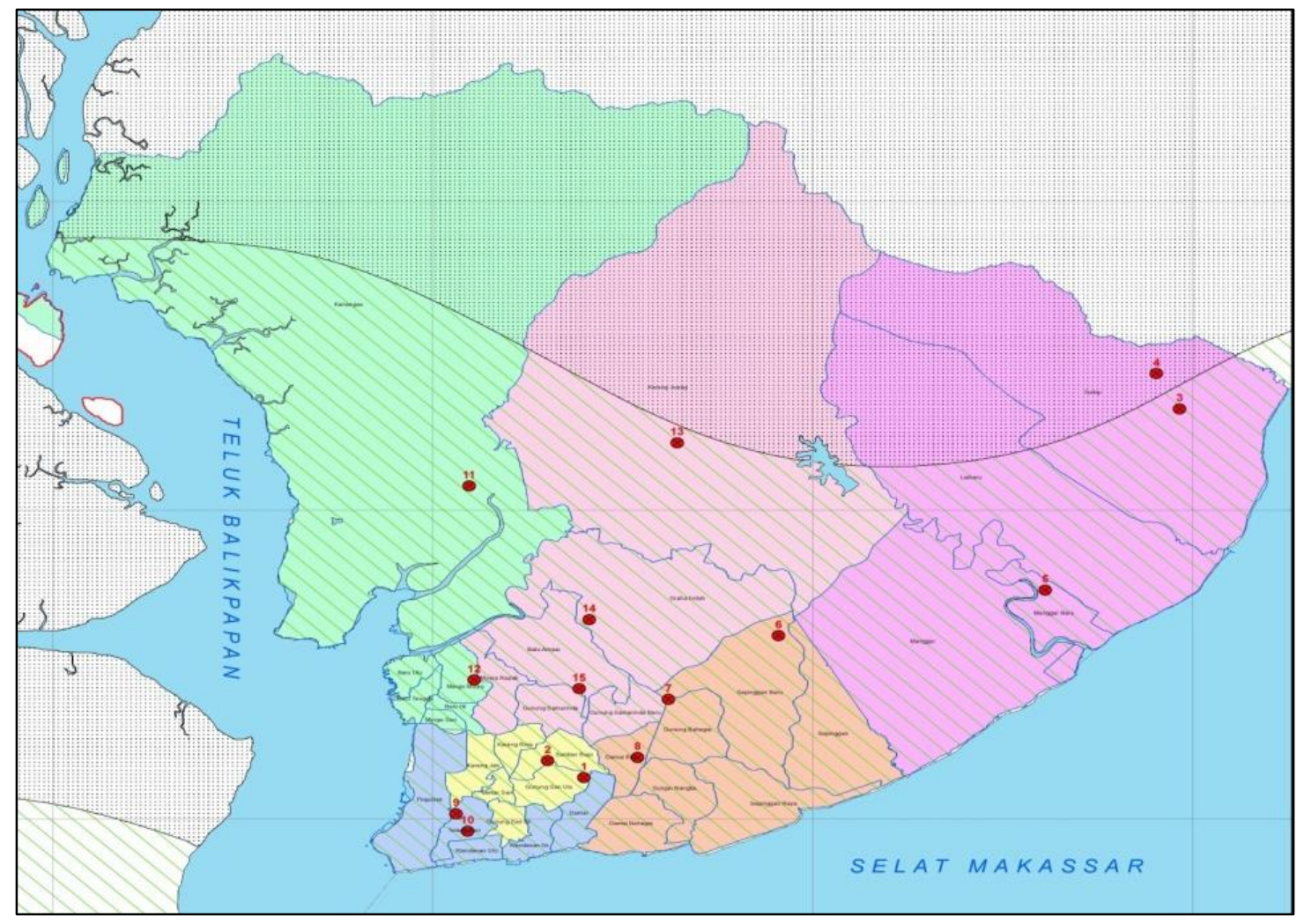

Figure. 1: Research Sites in Balikpapan City 
The $1^{\text {st }}$ International Conference on Business and Management of Technology (IConBMT)

August 3rd 2019, Institut Teknologi Sepuluh Nopember, Surabaya, Indonesia

Qualitative assessment of the infiltration rate obtained is based on infiltration rate classification by U.S. Soil Conservation [8], which can be seen in Table 1 .

TABLE 1 .

CLASSIFICATION OF INFILTRATION RATE [8]

\begin{tabular}{cc}
\hline \hline Class & Infiltration Rate (mm / hour) \\
\hline Very Fast & $>254$ \\
Fast & $>127-254$ \\
Rather Fast & $>63-127$ \\
Medium & $>20-63$ \\
Rather Slow & $>5-20$ \\
Slow & $1-5$ \\
\hline \hline
\end{tabular}

The rate of infiltration is obtained from the field using a Double-ring Infiltrometer. The data from the results of measuring the infiltration rate during the 5 minute interval from 15 location points in Balikpapan City can be seen in Table 2.

Table 2. shows that from the field measurements obtained a constant infiltration rate occurred in the 35 th minute to the 50th minute. the constant infiltration rate occurred at 35 minutes at 3 locations, 40 minutes at 2 points, 45 minutes at 3 points and at 50 minutes at 7 points. The rate of infiltration rate reaches a constant influenced by soil texture and soil surface conditions. The longer it takes the soil to reach constant because the soil texture is sand or the composition is more like sand. The surface conditions of the land that have been held such as in the locations of $\mathrm{SB}, \mathrm{T} 2$ and GI have resulted in faster soil infiltration rates.
The Horton model is one of the well-known infiltration models in hydrology. Horton acknowledges that infiltration capacity decreases with increasing time until it approaches a constant value. Horton stated that the decrease in infiltration capacity was more controlled by factors operating on the surface of the land compared to the flow process in the soil. Horton expressed his view that a decrease in infiltration capacity is more controlled by factors operating at the ground surface compared to the flow process in the soil. This model is very simple and more suitable for experimental data. The main weakness of this model lies in determining the parameters $\mathrm{fO}, \mathrm{fc}$, and $\mathrm{k}$ and is determined by data-fitting. Even so, with the advancement of computer systems this process can be done with a simple spreadsheet

From the measurement results, the value of fo is unknown. To obtain the fo value, the data in Table 2 are taken and illustrated in the extension of the infiltration curve of the Horton equation using the Sigmaplot application as shown in Figure 2. Figure 2 shows the extension of the Horton method infiltration fitting curve at the GSU location. Each location depicts the Horton infiltration fitting curve to get the value of fo per location point. From the analysis of the extension of the infiltration fitting curve above using the Sigmaplot application, a fo value of $0.17 \mathrm{~cm} \mathrm{/} \mathrm{minute} \mathrm{was} \mathrm{obtained} \mathrm{for} \mathrm{the} \mathrm{GSU}$ location.

Table 3 shows the results of calculating the infiltration rate at the GSU location. The data in Table 3 are then illustrated in a graph of the relationship between $t$ (time) and $\log (\mathrm{f}-\mathrm{fc})$ to find the gradient value $(\mathrm{m})$ like Figure 3.

TABLE 2 .

FIELD MEASUREMENT RESULTS

\begin{tabular}{|c|c|c|c|c|c|c|c|c|c|c|c|c|c|c|c|c|}
\hline \multirow{2}{*}{ No } & \multirow{2}{*}{ Time (t) (minutes) } & \multicolumn{15}{|c|}{ Difference in water level (cm) } \\
\hline & & GSU & $\mathbf{S R}$ & T1 & $\mathbf{T 2}$ & MB & SB & GB & DB & Prap & TS & Kari & MM & $\mathbf{K J}$ & GI & BA \\
\hline 1 & 5 & 0,8 & 2,2 & 0,5 & 0,9 & 1,8 & 0,3 & 0,5 & 2,1 & 2,7 & 2,9 & 4 & 1 & 0,4 & 0,4 & 2 \\
\hline 2 & 10 & 0,75 & 2 & 0,3 & 0,6 & 1,4 & 0,25 & 0,5 & 2,1 & 2,65 & 2,6 & 3,6 & 0,9 & 0,4 & 0,4 & 1,3 \\
\hline 3 & 15 & 0,7 & 1,5 & 0,2 & 0,4 & 1,2 & 0,25 & 0,45 & 2 & 2,6 & 2,3 & 2,2 & 0,75 & 0,3 & 0,35 & 1,1 \\
\hline 4 & 20 & 0,65 & 1,3 & 0,2 & 0,2 & 1,2 & 0,2 & 0,45 & 2 & 2,55 & 2,2 & 1 & 0,6 & 0,3 & 0,35 & 1,1 \\
\hline 5 & 25 & 0,6 & 1 & 0,2 & 0,2 & 1,1 & 0,2 & 0,45 & 1,8 & 2,5 & 2,1 & 0,9 & 0,6 & 0,3 & 0,3 & 0,8 \\
\hline 6 & 30 & 0,55 & 1 & 0,2 & 0,2 & 1,1 & 0,15 & 0,4 & 1,8 & 2,4 & 1,9 & 0,8 & 0,5 & 0,2 & 0,3 & 0,7 \\
\hline 7 & 35 & 0,53 & 0,8 & 0,2 & 0,1 & 1,1 & 0,1 & 0,4 & 1,6 & 2,4 & 1,8 & 0,75 & 0,5 & 0,2 & 0,2 & 0,6 \\
\hline 8 & 40 & 0,52 & 0,8 & 0,2 & 0,1 & 1 & 0,1 & 0,3 & 1,5 & 2,3 & 1,7 & 0,7 & 0,5 & 0,2 & 0,2 & 0,5 \\
\hline 9 & 45 & 0,5 & 0,75 & 0,1 & 0,1 & 1 & 0,1 & 0,3 & 1,2 & 2,2 & 1,6 & 0,7 & 0,4 & 0,1 & 0,2 & 0,5 \\
\hline 10 & 50 & 0,4 & 0,6 & 0,1 & 0,1 & 0,9 & 0,1 & 0,3 & 0,9 & 2 & 1,4 & 0,7 & 0,4 & 0,1 & 0,2 & 0,4 \\
\hline 11 & 55 & 0,4 & 0,6 & 0,1 & 0,1 & 0,9 & 0,1 & 0,3 & 0,9 & 2 & 1,4 & 0,7 & 0,4 & 0,1 & 0,2 & 0,4 \\
\hline 12 & 60 & 0,4 & 0,6 & 0,1 & 0,1 & 0,9 & 0,1 & 0,3 & 0,9 & 2 & 1,4 & 0,7 & 0,4 & 0,1 & 0,2 & 0,4 \\
\hline
\end{tabular}


The $1^{\text {st }}$ International Conference on Business and Management of Technology (IConBMT) August 3rd 2019, Institut Teknologi Sepuluh Nopember, Surabaya, Indonesia

TABLE 3.

RESUlts of HoRton MOdel INFILTRATION RATE CALCUlation AT GSU LOCATIONS

\begin{tabular}{ccccccc}
\hline \hline No & Waktu (t) (menit) & Penurunan (cm) & Laju Infiltrasi (f) $(\mathbf{c m} / \mathbf{m e n i t})$ & $\mathbf{f c}(\mathbf{c m} / \mathbf{m e n i t})$ & $\mathbf{f - f c}(\mathbf{c m} / \mathbf{m e n i t})$ & Log (f-fc) \\
\hline & 0 & & 0,17 & 0,08 & 0,09 & $-1,036$ \\
1 & 5 & 0,80 & 0,16 & 0,08 & 0,08 & $-1,097$ \\
2 & 10 & 0,75 & 0,15 & 0,08 & 0,07 & $-1,155$ \\
3 & 15 & 0,70 & 0,14 & 0,08 & 0,06 & $-1,222$ \\
4 & 20 & 0,65 & 0,13 & 0,08 & 0,05 & $-1,301$ \\
5 & 25 & 0,60 & 0,12 & 0,08 & 0,04 & $-1,398$ \\
6 & 30 & 0,55 & 0,11 & 0,08 & 0,03 & $-1,523$ \\
7 & 35 & 0,53 & 0,11 & 0,08 & 0,03 & $-1,585$ \\
8 & 40 & 0,52 & 0,10 & 0,08 & 0,02 & $-1,620$ \\
9 & 45 & 0,50 & 0,10 & 0,08 & 0,02 & $-1,699$ \\
10 & 50 & 0,40 & 0,08 & 0,08 & 0,00 & \\
11 & 55 & 0,40 & 0,08 & 0,08 & 0,00 & \\
12 & 60 & 0,40 & 0,08 & 0,08 & 0,00 & \\
\hline \hline
\end{tabular}



Figure 3: Curve looking for the $\mathrm{m}$ gradient at the GSU location.

TABLE 4.

INITIAL INFILTRATION RATE (FO), CONSTANT INFILTRATION RATE (FC) AND INFILTRATION CAPACITY (F) WITH THE HORTON METHOD

\begin{tabular}{ccccccc}
\hline No & Location & $\boldsymbol{f o}(\mathbf{c m} / \mathbf{m i n u t e})$ & $\boldsymbol{f} \boldsymbol{c}(\mathbf{c m} / \mathbf{m i n u t e})$ & Gradient $(\mathbf{m})$ & $\mathbf{K}$ & $\boldsymbol{f}(\mathbf{c m} / \mathbf{m i n u t e})$ \\
\hline 1 & GSU & 0,172 & 0,08 & $-0,0154$ & 149,620 & 0,088 \\
2 & SR & 0,560 & 0,12 & $-0,0271$ & 85,024 & 0,227 \\
3 & T1 & 0,158 & 0,02 & $-0,0193$ & 119,386 & 0,039 \\
4 & T2 & 0,293 & 0,02 & $-0,0421$ & 54,730 & 0,130 \\
5 & MB & 0,438 & 0,18 & $-0,0233$ & 98,890 & 0,230 \\
6 & SB & 0,072 & 0,02 & $-0,0184$ & 125,225 & 0,026 \\
7 & GB & 0,109 & 0,06 & $-0,0107$ & 215,341 & 0,061 \\
8 & DB & 0,481 & 0,18 & $-0,0120$ & 192,012 & 0,192 \\
9 & PRAP & 0,563 & 0,40 & $-0,0117$ & 196,936 & 0,406 \\
10 & TS & 0,630 & 0,28 & $-0,0201$ & 114,634 & 0,332 \\
11 & KARI & 1,308 & 0,14 & $-0,0664$ & 34,701 & 0,795 \\
12 & MM & 0,245 & 0,08 & $-0,0255$ & 90,359 & 0,117 \\
13 & KJ & 0,049 & 0,02 & $-0,0154$ & 149,620 & 0,022 \\
14 & GI & 0,094 & 0,04 & $-0,0144$ & 160,010 & 0,044 \\
15 & BA & 0,092 & 0,02 & $-0,0154$ & 149,620 & 0,026 \\
\hline
\end{tabular}


Figure 3 shows a graph with a linear equation $\mathrm{y}=-$ $0.0154 \mathrm{x}-1.0184$ which is the result of the Horton curve at the GSU location. From the linear equation, the $\mathrm{m}=$ 0,0154 gradient is obtained. To find the value of $K$, the formula $\mathrm{K}=-1 / 0.434 \mathrm{~m}$ is used so that the $\mathrm{K}$ value of 149.62 is obtained.

Table 4 shows the results of calculating the initial infiltration rate (fo), constant infiltration rate (fc) and infiltration capacity (f) with the Horton method. The calculation steps for 14 other location points use the same steps as in Figure 1, Figure 2 and Table 3. The gradient values of 15 research location points are in the range of 0.0107 up to -0.0664 , while the $\mathrm{K}$ values obtained are in the range 34,701 to 215,341 . The value of the gradient obtained is inversely proportional to the value of $K$ produced. The greater the gradient value, the smaller the value of $K$. By entering the value $K$ into the Horton equation, the value of infiltration capacity will be obtained.

From Table 4, it can be concluded that Kariangau (Kari) has the highest initial infiltration rate of $1.308 \mathrm{~cm} /$ minute, while the lowest initial infiltration rate is in Sepinggan Baru (SB) which is $0.795 \mathrm{~cm} /$ minute. Constant infiltration rate is the maximum infiltration rate in situations where the ability of the soil has reached its maximum in absorbing water into the soil. The highest infiltration value that is highest is in the Prapatan (Prap) Village, which is $0.40 \mathrm{~cm} /$ minute. The lowest constant infiltration values are in Teritip Sub-District, Sepinggan Baru, Karang Joang and Batu Ampar which are $0.02 \mathrm{~cm} \mathrm{/} \mathrm{minute.} \mathrm{Infiltration}$ capacity is the maximum infiltration rate obtained from a particular type of soil. The largest infiltration capacity is in Kariangau Village with a value of $0.795 \mathrm{~cm} /$ minute and the smallest is in Karang Joang Village with a value of $0.022 \mathrm{~cm} /$ minute.

Table 5 shows the results of the infiltration rate classification in 15 research locations in Balikpapan City based on U.S. Soil Conservation. The infiltration rate classification in Balikpapan City is divided into four classes, namely fast, rather fast, medium and rather slow. The locations that included the rapid infiltration rate group were 2 (two) locations, namely Prapatan and Telaga Sari. The locations included in the infiltration rate group are rather fast, there are 4 (four) locations, namely Sumber Rejo, Manggar Baru, Damai Baru and Kariangau. Locations including the infiltration rate group are 4 (four), namely Gunung Sari Ulu, Gunung Bahagia, Margo Mulyo and Graha Indah. Locations which include the infiltration rate group are 5 (five), which are Teritip 1, Teritip 2, Karang Joang, Sepinggan Baru and Batu Ampar.

Based on the ability to absorb water at a speed of more than 1 meter per day, the area that has the potential to be a rainwater catchment area of 10 locations is obtained from 15 locations namely Prapatan, Telaga Sari. Sumber Rejo, Manggar Baru, Damai Baru, Kariangau, Gunung Sari Ulu, Margo Mulyo, Gunung Bahagia and Graha Indah. So the area with potential as a catchment area is around $60 \%$ of all research locations.

Land with a low infiltration capacity is defined as land with a steady state infiltration rate equal to or less than 0.06 inches per hour. The City land survey is useful for initial screening to identify land that may have a low infiltration rate. This survey is not accurate enough to determine location-specific characteristics suitable for infiltration systems but is useful for initial screening.

The limitations of rainwater management in areas with narrow soils generally block large-scale infiltration and groundwater infiltration (infiltration that enters the groundwater system). Rainwater management is a common problem due to increased development in areas that are catchment areas. Floods that occur in urban areas are a big challenge to reduce damage and water quality. The concept of management in Best Management Practices (BMPs) covers a variety of things that are appropriate to technology and activities intended to minimize the effects of rainwater runoff.

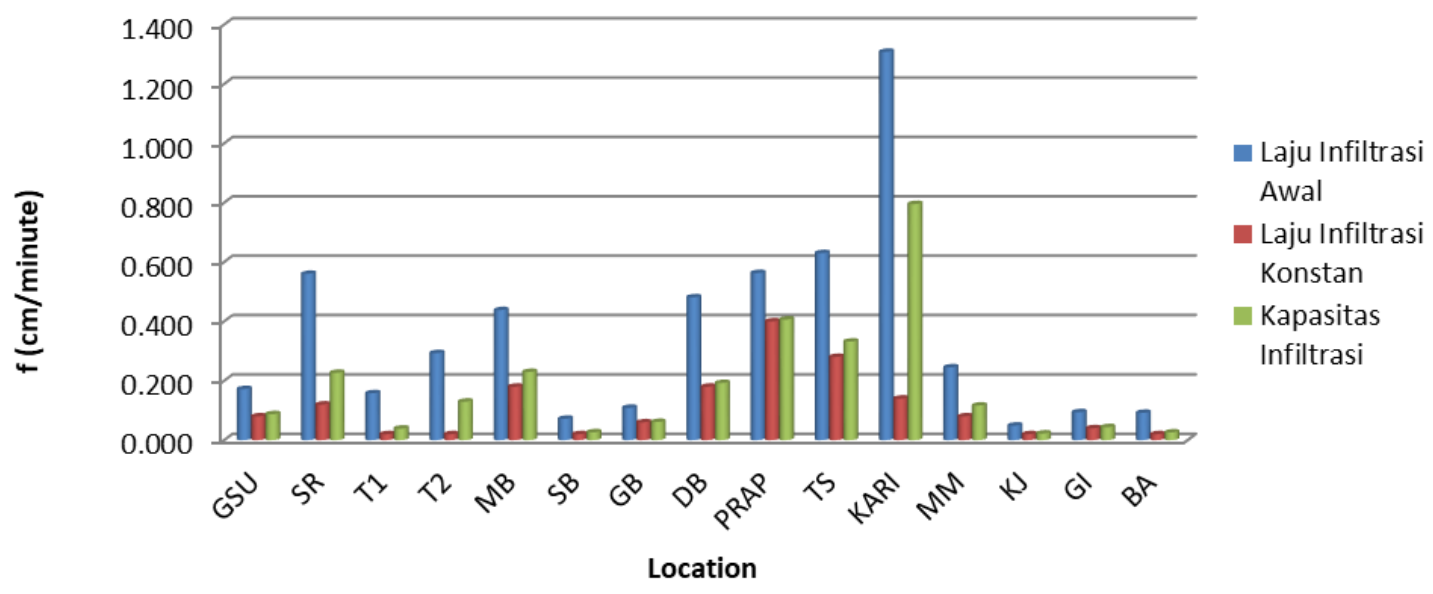

Figure 4. Graph Comparison of Initial Infiltration Rate, Constant Infiltration Rate and Infiltration Capacity 
TABEL 5

INFILTRATION RATE CLASSIFICATION RESULTS

\begin{tabular}{ccccc}
\hline \hline No & Location & Infiltration Rate (cm/minute) & Infiltration Rate $(\mathbf{m m} / \mathbf{h o u r})$ & Class \\
\hline 1 & GSU & 0,08 & 48 & Medium \\
2 & SR & 0,12 & 72 & Rather Fast \\
3 & T1 & 0,02 & 12 & Rather Slow \\
4 & T2 & 0,02 & 12 & Rather Slow \\
5 & MB & 0,18 & 108 & Rather Fast \\
6 & SB & 0,02 & 12 & Rather Slow \\
7 & GB & 0,06 & 36 & Medium \\
8 & DB & 0,18 & 108 & Rather Fast \\
9 & PRAP & 0,4 & 240 & Fast \\
10 & TS & 0,28 & 168 & Fast \\
11 & KARI & 0,14 & 84 & Rather Fast \\
12 & MM & 0,08 & 48 & Medium \\
13 & KJ & 0,02 & 12 & Rather Slow \\
14 & GI & 0,04 & 24 & Medium \\
15 & BA & 0,02 & 12 & Rather Slow \\
\hline \hline
\end{tabular}

Examples of BMP to reduce rainwater runoff include infiltration trenches, grass blocks, grasses, swales, buffer strips, detention, retention, and bioretency basins. Traditional technical approaches to water management tend to focus on structural BMPs such as detention and reservoirs. Over the past few decades, both detention facilities and retention facilities have become the most commonly used techniques for controlling the effects of rainwater runoff.

Low amount of infiltration, type, location, amount, and / or size of infiltration BMP that can be used for rainwater management. Infiltration rates that take longer to protect rainwater can damage vegetation, cause mosquito breeding, damage soil structure, and reduce pollutant treatment by BMP. This does not mean that this land has no recharge and refill capability. It is possible for areas with slow infiltration rates, to meet infiltration purposes that appropriate design modifications are needed, such as changing the soil with compost or sand, or incorporating the underdrain into practice. From the results of the study, the research locations were mostly on plans for housing, education and trade and services. In the area of housing, education, trade and services with rapid infiltration rates, rather fast and moderate, rainwater management in buildings and parcels can use PAH facilities and / or retention facilities. The use of both rainwater management methods in buildings and parcels can be done together or choose one method. The choice of method is done by looking at the condition of the region. PAH facilities are needed if the land needed to make means of limited retention. For example, in one house requires 2 (two) infiltration wells, but limited land, so that PAH facilities can be added in the form of reservoirs. If the available land is sufficient, it can only use retention facilities such as infiltration wells and / or biopori. If the land for retention facilities is not available because it has already been built, then it can use PAH facilities.

In the area of housing, education, trade and services with infiltration rather slowly, rainwater handling in buildings and parcels can use Rainwater Shelter facilities and / or retention facilities and / or detention facilities. The method of using the three rainwater management methods in buildings and parcels can be done together or choose one method. The means of retention can be used to continue groundwater at a minimum of $1.5 \mathrm{~m}$ in the rainy season and land conditions still allow for facility retention. The means of PAH and detention facilities using the built land cannot use the means of retention. Detention facilities that are used in relation to land have very shallow groundwater so it is impossible to absorb rainwater, depending on the very dense settlements and prioritized in areas containing topography contributing to rainwater in the downstream area.

Rainwater storage facilities (PAHs) can consist of tanks, ponds, air tanks, reservoirs, etc. whose dimensions are calculated based on the volume of flood shares. Rainwater collected in rainwater storage facilities can be used by building owners / users for daily activities. Rainwater storage $(\mathrm{PAH})$ can be used provided that the minimum rainfall is at least $1300 \mathrm{~mm} /$ year. Meanwhile, Balikpapan City has a high rainfall of $>1300 \mathrm{~mm} /$ year.

Rainwater that is slapped by using PAH can be used for daily needs. Rainwater in Balikpapan City has a pH of 5.3 below the ideal $\mathrm{pH}$ for rainwater quality, which is 5.6 (BMKG, 2019). If the $\mathrm{pH}$ is below the ideal $\mathrm{pH}$, the acid is not feasible and is suitable for use as drinking water, while the ideal $\mathrm{pH}$ for drinking water is 6-7. If rainwater is to be used as a source of raw water for drinking water that was done previously. 
Retention facilities can be made infiltration wells, retention ponds and biopores that are needed for collection and infuse rainwater into the ground. Detention facilities can be in the form of tanks / detention pools, vertical parks, roof gardens and other similar technologies that function to collect water temporarily so as not to overflow before being channeled into urban drainage. Infiltration wells are one of the cheap and fast solutions to flood problems. In general, infiltration wells are circular in diameter with a minimum of 1 meter. The upper excavation hole until the soil layer is relatively hard and cemented to be protected by the well wall avalanche containment field (can be from bamboo, masonry, concrete base or drum). The depth of infiltration wells is relatively dependent on the condition of rock formations and groundwater level. For areas with deep water table, the depth of infiltration wells can be made up to 5 meters. Ideally in drainage planning in an area it is necessary to plan for infiltration wells so that the dimensions of the drainage can be minimized. For more maximal results, the use of infiltration wells can be varied with other drainage structures such as infiltration ponds.

In residential areas with limited plot sizes, for example simple or very simple housing complexes, placement of infiltrated wells that meet the requirements will experience difficulties. To overcome this problem, it is necessary to create a collective (joint) infiltration well where one collective infiltration well can serve several houses, for example per block or per RT, or a wider area. To ensure that water flows smoothly, collective infiltration wells should be placed on the lowest land in the area served.

\section{CONCLUSION}

The results showed that the results of measurements of infiltration rates in the field showed that Balikpapan City had an infiltration rate between the range of $12 \mathrm{~mm} /$ hour to $240 \mathrm{~mm} /$ hour. Based on U.S. Soil Conservation, the infiltration rate classification in Balikpapan City is divided into four infiltration rate classes, namely fast, rather fast, medium and rather slow. Areas that have the potential to be rainwater catchment areas are seen from areas that have as many as 10 locations from 15 locations, namely Prapatan, Telaga Sari. Sources Rejo, Manggar Baru, Damai Baru, Kariangau, Gunung Sari Ulu, Margo Mulyo, Graha Indah and Mount Bahagia. So the area that has the potential as a catchment area is around $60 \%$ of all research locations.

From the analysis results obtained by the type of rainwater management facilities in the form of PAHs and / or retention facilities for housing, education, trade and services with rapid, rather rapid infiltration, while PAHs and / or retention facilities and / or detention facilities for infiltration rates. a little slow.

\section{REFERENCE}

[1] C. Apollonio, G. Balacco, A. Novelli, E. Tarantino, and A. F. Piccinni, "Land use change impact on flooding areas: The case study of Cervaro Basin (Italy)," Sustainability, vol. 8, no. 10, pp. 1-18, 2016.

[2] J. Lu, F. Zheng, G. Li, F. Bian, and J. An, "The effects of raindrop impact and runoff detachment on hillslope soil erosion and soil aggregate loss in the Mollisol region of Northeast China," Soil Tillage Res., vol. 161, pp. 79-85, Aug. 2016.

[3] R. A. Shakesby, S. H. Doerr, and R. P. D. Walsh, "The erosional impact of soil hydrophobicity: Current problems and future research directions," in Journal of Hydrology, 2000, vol. 231-232, pp. 178-191.

[4] J. D. Walker et al., "Reduced raindrop-impact driven soil erosion by infiltration," J. Hydrol., vol. 342, no. 3-4, pp. 331335, Sep. 2007.

[5] R. Angulo-Jaramillo et al., "An Introduction to Soil and Water Infiltration," in Infiltration Measurements for Soil Hydraulic Characterization, Switzerland: Springer International Publishing, 2016, pp. 1-42.

[6] M. A. Dhalhar, "Process and field evaluation of infiltration rate. A 'PlanB."' The University of Minnesota, 1972.

[7] A. S. Tricker, "The infiltration cylinder: Some comments on its use," J. Hydrol., vol. 36, no. 3-4, pp. 383-391, 1978.

[8] H. Kohnke, Soil physics. New York: McGraw-Hill Inc., 1968. 